\title{
A la Recherche du Temps Perdu: The Constitutionality of Denial of Credit on Revocation of Parole
}

Parole laws serve the important function of providing an intermediate status between incarceration and outright release from custody. They are designed both to promote the rehabilitation of the prisoner and to facilitate his reintegration into society. ${ }^{1}$ One aspect of parole which has been frequently criticized as inconsistent with its purposes is statutory denial of credit for time spent on parole. Such statutes provide that when a violation of parole results in revocation, the prisoner be reincarcerated for the unserved portion of his sentence computed from the date of release from prison and undiminished by the time spent on parole. Provisions of this sort have met with disfavor in numerous state legislatures; many state parole statutes provide that parole violators be returned to prison for that period remaining on their sentence at the time of parole revocation. ${ }^{2}$ Credit is thus granted at least for the time the prisoner had spent on parole prior to his violation. Some jurisdictions, however, retain denial of credit provisions in their parole statutes; the most notable of these is section 4205 of the federal law. ${ }^{3}$

1 See generally G. Giardini, Parole Process, especially at 19 (1959). See also W. Lunden, The Iowa Parole System 2-3 (1964); Woods v. Steiner, 207 F. Supp. 945 (D. Md. 1962).

2 See Moder Penal Code § 305-22, Comment (Tent. Draft No. 5, 1956). The most significant change since 1956 occurred in New York. Prior to an amendment of the parole law in 1960, a parolee was not given credit for his parole time if he committed a felony while on parole. Today, the parole violator receives credit for his time on parole regardless of the nature of the violation. N.Y. CORREC. LAw \& 219. In none of the states granting credit in 1956 is it denied today.

3 A warrant for the retaking of any United States prisoner who has violated his parole, may be issued only by the Board of Parole or a member thereof and within the maximum term or terms for which he was sentenced. The unexpired term of imprisonment of any such prisoner shall begin to run from the date he is returned to the custody of the Attorney General under said warrant, and the time the prisoner was on parole shall not diminish the time he was sentenced to serve.

18 U.S.C. $\S 4205$ (1964) (emphasis added). Section 4205 must be read in conjunction with the discretion given the parole board in a subsequent section of the Act:

A prisoner retaken upon a warrant issued by the Board of Parole, shall be given an opportunity to appear before the Board, a member thereof, or an examiner designated by the Board.

The Board may then, or at any time in its discretion, revoke the order of parole and terminate such parole or modify the terms and conditions thereof.

If such order of parole shall be revoked and the parole so terminated, the said 
Denial of credit statutes are designed to maximize both deterrence and administrative flexibility. The realization that a return to prison will result in the loss of time spent on parole adds to the parolee's incentive to act lawfully. The threat, during the entire period of parole, of reinstatement of a substantial term in prison upon violation of parole permits parole officials to supervise the conduct of those under their control without the necessity of criminal prosecution before a court. ${ }^{*}$ If they determine to their own satisfaction that a violation has occurred, they can simply return the parolee to prison for a lengthy stay. By contrast, in those states that credit parole time despite violation and revocation, the potential period of imprisonment to which the prisoner is subject diminishes as the period of parole continues. Hence, the parole officials slowly lose the sanctions at their disposal.

The discretionary power granted to parole boards under section 4205 and its state analogues has been subjected to constitutional attack. ${ }^{5}$ Parole revocation itself is constitutionally valid, although there has been litigation concerning the procedural safeguards which the board must afford in establishing a violation. ${ }^{6}$ But permitting the board to deny credit for time served prior to revocation introduces additional problems. The essential distinction between simple revocation and revocation accompanied by denial of credit is the difference between the mode of custody and the duration of custody: while revocation merely provides that a prisoner's sentence be spent in prison, denial of credit actually extends the period of custody beyond that originally

prisoner may be required to serve all or any part of the remainder of the term for which he was sentenced.

18 U.S.C. \& 4207 (1964).

4 For the approach of the American Law Institute to the role of revocation as a sanction for parole violation, see Moder Penal Code, § 305.19, Comment (Tent. Draft No. 5, 1956).

5 See, e.g., Hodge v. Markley, 339 F.2d 973 (7th Cir. 1965); Van Buskirk v. Wilkinson, 216 F.2d 735 (9th Cir. 1954); Hedrick v. Steele, 187 F.2d 261 (8th Cir. 1951) (upholding $\S$ 4205). See also Dolan v. Swope, 138 F.2d 301 (7th Gir. 1943) (upholding predecessor of \$ 4205); Bates v. Rivers, 323 F.2d 311 (D.C. Cir. 1963) (upholding District of CoIumbia ordinance analogous to $\S 4205$ ); Woods v. Steiner, 207 F. Supp. 945 (D. Md. 1962) (upholding similar Maryland statute).

The only successful attack on an application of $\S 4205$ is Gibbs v. Blackwell, 354 F.2d 469 (5th Cir. 1965). In Gibbs the circuit court remanded the case so that the district court could ascertain more facts and determine whether the application of $\S 4205$ to the facts seemingly involved would be unconstitutional. There is no further record of the case. For further discussion of Gibbs, see note 42 infra.

In Bates v. Rivers, 323 F.2d at 312-15, Judge J. Skelly Wright in dissent indicated that he considers statutes denying credit to parole violators for time spent on parole unconstitutional.

6 Hyser v. Reed, 318 F.2d 225 (D.C. Cir.), cert. denied, 375 U.S. 957 (1963). For a dated but interesting discussion of procedural safeguards in parole revocation see Note, Parole Revocation Procedures, 65 HARv. L. REv. 309 (1951). 
imposed. ${ }^{7}$ Since the denial of credit is administratively imposed under procedures far less stringent than those required for incarceration, section 4205 is open to attack on the ground that it denies liberty without due process of law. This comment will examine the constitutionality of revocation of parole without crediting the time to the expiration of the prisoner's sentence.

\section{Constitutional Ghallenges to Section 4205}

\section{Imposition of Custody Without Proper Procedures}

The primary attack on section 4205 may be stated very briefly. If credit is denied for time spent on parole, it is apparent that upon completion of his sentence the prisoner will have served in parole custody and in prison a greater period than that provided for in his original sentence. As a result, the action of the board in denying credit results in the imposition of custody. Since, as has already been mentioned, this imposition takes place under procedures far less stringent than those required at a trial, it appears to constitute a denial of liberty without due process of law.

While the constitutional challenge may be stated quickly, the defenses are complicated indeed. Two major arguments have been used. The first is that parole is really freedom and that the time on parole cannot be said to be a way of serving a sentence in custody. ${ }^{8}$ The second is that parole time is not a part of the term of years imposed at sentence, but is a supplemental form of custody imposed by implication by the sentencing judge. ${ }^{9}$ Both of these arguments lead to the conclusion that parole time does not satisfy the sentence and that denial of credit for this time merely ensures that the sentence will be served in full. Underlying these arguments is the sentiment that section 4205 merely gives a form of administrative discretion over duration of sentence which the courts have in the past permitted. ${ }^{10}$

a. The freedom theory. The simplest defense to constitutional attacks on section 4205 is to maintain that parole is freedom and that

7 Interestingly enough, this contention was apparently made in Fyser v. Reed, 318 F.2d at 233. However, the opinion indicates that it was not considered, for the court merely dealt with the requisite procedures for revocation.

8 "Appellant is not entitled to have the time he was at liberty on conditional release or parole treated as time served on his sentence when there has been a violation of the terms of the conditional release or parole." Hedrick v. Steele, 187 F.2d 261, 262 (8th Cir. 1951) (emphasis added).

9 See, e.g., Woods v. Steiner, 207 F. Supp. 945, 950 (D. Md. 1962), and text accompanying notes $2 \mathrm{l}-32$ infra.

10 For a discussion of administrative discretion over prisoners' sentences, see 1 K.C. Davis, Administratrve Law Treatise $\$ 2.13$ (1958). 
denial of credit for parole time can in no way extend the prisoner's sentence. There is no doubt that parole is preferable to prison confinement and that the lot of the parolee is far more favorable than that of the prisoner. But it seems equally clear that the parolee is not free.

The theories underlying parole seem to require that it involve substantial deprivations of liberty. Parole has two major raisons d'être, both of which demand close control over the parolee's life. First, parole is believed to be an effective method of supervising a prisoner's reintegration into society. Second, parole is thought to be an inexpensive way for penal officials to maintain control over those prisoners whom it would be wasteful for society to continue to feed and clothe, but whom it would be unwise to release outright. ${ }^{11}$ Both aspects involve some freedom, but they also necessitate continued control.

Practice as well as theory tends to support the position that parole is not freedom. Parolees are denied basic civil rights guaranteed under the Constitution. Warrants for the arrest of a parolee need not be so formal as warrants for the arrest of a free citizen; often they are required only to state that the parolee is suspected of a parole violation. ${ }^{12}$ Constitutional safeguards against search and seizure may not apply to parolees. ${ }^{13}$ And most significantly, nothing resembling full due process procedures is required to return a parolee to prison. ${ }^{14}$

Not only are a parolee's civil rights curtailed, but his everyday life is closely supervised and regulated. The parole board must approve the job a parolee takes as well as any subsequent occupational changes. Parolees are severely limited in their mobility, and their residences are generally under the control of the parole board. A parolee may not

11 "The purpose of parole legislation is to permit a deserving prisoner to leave prison before the expiration of his term and to serve out its balance while living in the community. Parole is an extension of the prison walls, an institution intended to achieve maximum prisoner rehabilitation at a minimal cost to the state." Woods v. Steiner, 207 F. Supp. 945, 951 (D. Md. 1962). See also Grardini, supra note 1, especially at 19. The beneficial objectives and the economies of parole are discussed in LuNDEN, supra note 1 , at $2-3,85-88$.

12 See the leading case of United States ex rel. Nicholson v. Dillard, 102 F.2d 94, 96 (4th Cir. 1939): "[A] warrant issued by the Parole Board for the arrest of a paroled prisoner is not to be judged by the same standards as a warrant for the arrest of one merely charged with crime ... . The prisoner's guilt of crime has already been adjudged, sentence of imprisonment has been imposed upon him, and the purpose of the warrant is merely to restore him to custody and 'to advise him of the purpose of his reincarceration.'"

13 See, e.g., the recent case of Echols v. State, 201 So. $2 d 89$ (Fla. Dist. Ct. App. 1967).

14 The standards imposed by Hyser v. Reed, 318 F.2d 225 (D.C. Cir.), cert. denied, 375 U.S. 957 (1963), have required parole boards to give the prisoner some procedural rights in reincarceration proceedings. These rights, however, fall far short of those required at a criminal trial. 
marry without the consent of the board. Usually he is forbidden to drink. ${ }^{15}$

The Supreme Court seems to be convinced that parole entails custody. Even in Anderson $v$. Corall, ${ }^{16}$ where the denial of credit was approved, the Court observed:

While on parole the convict is bound to remain in the legal custody and under the control of the warden until the expiration of the term, less allowance, if any, for good conduct. While this is an amelioration of punishment, it is in legal effect imprisonment. ${ }^{17}$

And in Jones $v$. Cunningham, ${ }^{18}$ a case in which the Supreme Court held that parole constituted sufficient custody to support a writ of habeas corpus, the Court ruled:

$[T]$ he custody and control of the Parole Board involve significant restraints on [a man's] liberty because of his conviction and sentence $\ldots .^{18}$

After reviewing many of the actual restrictions the Court observed:

[The parolee] must not only faithfully obey these restrictions and conditions but he must live in constant fear that a single deviation, however slight, might be enough to result in his being returned to prison .... . ${ }^{20}$

The freedom theory appears to be untenable.

b. Contemplation argument. A great number of courts have insisted that while parole may involve custody amounting to deprivation of liberty, it is not a form of custody which satisfies a prison sentence. ${ }^{21}$ These courts have declared that the term of years of a sentence may only be served by actual incarceration. ${ }^{22}$ They have in effect main-

15 See generally C. Newman, Sourcebook on Probation, Parole and Pardons 200-08 (2d ed. 1964); D. Dressler, Practice and Theory of Probation and Parole $171-99$ (1959); W. La Roe, JR., Parole WIth HoNor 144-53 (1939). See also Giardini, supra note 1, at 270-72 (Pa. Rules, Regulations \& Conditions Governing Parole).

16263 U.S. 193 (1923). For a discussion of this case, see text accompanying note 38 infra.

17 Id. at 196.

18371 U.S. 296 (1963).

19 Id. at 242.

$20 I d$.

21 See, e.g., Dolan v. Swope, 138 F.2d 301, 303 (7th Cir. 1943). See also Woods v. Steiner, 207 F. Supp. 945, 951 (D. Md. 1962): "[U]nder the parole statute in question here, a prisoner might remain in the custody of state authorities for a period in excess of the term of sentence originally imposed. .." (emphasis added).

22 See, e.g., Howard v. United States, 274 F.2d 100 (8th Cir. 1960); Yates v. Looney, 250 F.2d 956 (10th Cir. 1958). Or, as stated in Woods v. Steiner, 207 F. Supp. 945,950 (D. Md. 1962): "[T]he imprisonment contemplated in the imposition of sentence is confinement in fact." 
tained that parole is automatically imposed at the original sentencing as an additional and distinct part of the sentence; judges "contemplate" that those who are sentenced to a term of years in prison are liable to serve an additional period in the custody of the parole board. "In legal contemplation, the terms of the apposite parole statutes are implicitand, oftentimes, quite explicit-in the pronouncement of sentence."23 Thus parole, while custody, is not custody which satisfies the terms of a sentence.

This conception of parole is said to be a complete defense to the attacks made on section 4205. Denial of credit, instead of resulting in the imposition of additional custody, merely ensures that the entire period which the convict was sentenced to spend in incarceration will be served in prison. Under this view, denial of credit does not represent refusal to grant credit for time served, but is a mere withholding of that legislative grace which permits parole boards, under appropriate circumstances, to grant credit towards the term of incarceration for time not actually spent in incarceration. ${ }^{24}$ Since denial of credit involves no imposition of custody, the procedural due process problems are said to disappear.

This is the argument which most of the courts upholding the constitutionality of section 4205 have in one form or another accepted.25 Yet it is not a totally satisfactory rejoinder to the contention that requiring parolees to spend time in jail which they could not otherwise have been compelled to serve involves imposition of custody. When carefully analyzed, this argument proves too much. If constitutionality follows from the mere fact that imposition of custody may be characterized as "contemplated" by the original sentence, then a statute granting any form of discretion to administrative officials over sentences must be declared valid. Not only is it easy to imagine such forms of discretion which would be struck down, ${ }^{26}$ but courts have in fact overturned

23 Woods v. Steiner, 207 F. Supp. 945, 950 (D. Md. 1962).

24 "[B]ecause parole is a matter of legislative grace, its being granted may be coupled with such conditions as reasonably might be expected to assure its success. . . [ [I]f a federal or Maryland prisoner fulfills the conditions of his parole throughout the entire period of his release, he is entitled to credit on his sentence with the same legal effect as imprisonment." Id. at 951 .

25 The best judicial statement of this argument may be found in Woods $v$. Steiner. A1though courts often allude to one part or another of the argument outlined in the text, the constitutionality of $\S 4205$ has been so well settled on a stare decisis basis that most courts have apparently not felt it necessary to follow the argument through completely. See, e.g., Postelwait v. Willingham, 365 F.2d 759 (10th Cir. 1966).

28 For example, if prison officials were empowered by statute to impose fixed periods of additional custody for violations committed by prisoners, any extension of custody pursuant to this statute could be "justified" as fully contemplated by the sentencing judge and therefore an implied part of the original sentence. It is highly doubtful, 
legislation purporting to grant administrative discretion over the length of incarceration.

The Supreme Court of Illinois has voided two such statutes on the ground that they empowered administrative officials to impose punishment in violation of provisions of the state constitution. The first statute provided that when a prisoner was convicted of a crime, the trial judge should recommend a maximum and minimum sentence. ${ }^{27}$ This recommendation would be the prisoner's sentence unless subsequently changed by designated administrative officials. The second was a law which authorized penal officials to transfer to penitentiaries "incorrigible" juveniles committed to the state reformatory. ${ }^{28}$

The Illinois court could have upheld these measures on the same ground that the courts have invoked to reject the constitutional attacks on section 4205, viz., the punishment allegedly imposed by the administrative board was really part of the first sentence and the action of the board was not imposition but merely administration. Indeed, they were urged to do so. In the former case, it was argued that judicial recommendations were merely advisory and that the real sentence was the maximum and minimum imposed by law for the offense committed. ${ }^{29}$ In the second case, incarceration in the penitentiary was said to be an implied part of any sentence to the reformatory. ${ }^{30}$

Both arguments were rejected. In the first case, the court insisted that since the decision of the board changed what otherwise would have been the valid and binding sentence of the prisoner, its action amounted to imposition and not mere administration..$^{31}$ In the second case, the court indicated that determination as to the place of incarceration was a proper matter for administrative discretion if the discretion were within the judicially imposed bounds. But the court refused to use inference and implication to put the action of the board within the limits of the original sentence. ${ }^{32}$

The contemplation argument, in short, is an attempt to read into the original sentence an implied caveat that in addition to the period explicitly imposed, there is the possibility of an additional term of custody under the supervision of the parole board. In the situation in

however, that such a statute would be upheld; it would be obvious that despite any "justification," the additional custody was not a part of the original sentence but was, instead, imposed by prison officials.

27 [1941] Ill. Laws 560.

28 [1897] III. Laws 286.

29 People v. Montana, 380 Ill. 596, 44 N.E.2d 569 (1942).

30 People ex rel. Martin v. Mallary, 195 Ill. 582, 63 N.E. 508 (1902).

31380 Ill. at 605,44 N.E.2d at 575.

32195 IIl. at 593, 63 N.E. at 511. 
which the denial of credit results in the prisoner's being compelled to serve more time in custody than provided for by the maximum statutory penalty for the crime of which he was convicted, this caveat must be read into the statutory maximum. There is no logical way to refute this contemplation argument. But it seems to be a very strained justification for a questionable practice: an attempt to find something which is not really there. And it is also an argument which could be used to justify any grant of power to penal officials over prisoners' sentences.

c. The valid administration theory. It can be argued that even if in denying credit the parole board is determining the duration of sentence, this is valid administrative action and not illegal imposition. While determinations concerning penal confinement are not generally matters of administrative discretion, there are examples of administrative determinations concerning sentencing. Perhaps the most prominent example of such administrative discretion may be found in indeterminate sentencing laws. ${ }^{33}$

Indeterminate sentencing laws provide that the trial judge is not to pass sentence on a convicted prisoner. Rather, the prisoner is placed under the supervision and control of penal officials for an indeterminate term, the limits of which are the statutory maximum and minimum for the crime. The prisoner may not be released before serving the minimum term, nor may he be detained after the expiration of the statutory maximum. But within these limits, the penal officials may hold him or release him at their discretion. ${ }^{34}$

Such laws grant administrative officials considerable discretion over the duration of the prisoner's term of custody. This discretion is exercised without the procedural safeguards of a trial. In addition, the ultimate duration is determined long after trial. While these characteristics have led to constitutional challenges, the laws have been universally upheld. ${ }^{35}$ In sustaining these statutes, the courts did not content themselves with vague statements that the boards were operating within the contemplated limits of the sentence. Instead, they presented significant reasons why the discretion granted the boards should be permitted.

33 See, e.g., Ex parte Lee, 177 Cal. 690, 692-93, 171 P. 958, 959-60 (1918), and People v. Kostal, 15 Cal. App. 2d 444, 323 P.2d 1020 (1958), two of the leading cases upholding the California indeterminate sentencing law, CAL. Pen. CoDe § 1168. See also K.C. Davis, AdMINistrative LAW Treatise § 2.13 (1958).

34 See, e.g., CAL. PeN. CODE § 1168.

35 For an example of an attack on the application of an indeterminate sentencing law as a denial of due process of law, see People v. Joyce, 246 Ill. 124, 137, 92 N.E. 607, 613 (1910). Double jeopardy was the main attack in the California cases of Lee and Kostal, supra note 33. 
Two factors were found to be especially important. First, the inability of the administrative board to extend the duration of the prisoner's sentence beyond the maximum which he could be compelled to serve on the basis of the sentence alone was considered an essential limitation on the board's power. ${ }^{36}$ Second, the fact that the indeterminate sentencing laws were designed, not as a means of facilitating punishment, but with a view towards promoting leniency, was felt to negative the contentions that the exercise of the law resulted in denial of due process. ${ }^{37}$

These factors do not seem to be present under section 4205 . While the administrative officials cannot, under the indeterminate sentencing laws, extend the period of custody beyond that which could be compelled on the basis of the sentence alone, the federal parole board may extend the period of custody beyond that which could be compelled apart from their action. In terms of leniency, it must be observed that the parole statute is in general a benevolent statute. Nevertheless, section 4205 by itself is harsh indeed. Were section 4205 necessary in order for there to be an effective parole system, it might be justifiable. Indeed, in indeterminate sentencing laws, administrative action seems to be necessary in order to uphold a benevolent statute. But the viability of state parole statutes providing only for reincarceration upon parole violation but not for denial of credit is as good evidence as any that provisions like section 4205 are not needed to have an effective parole statute. In short, section 4205 is the antithesis of leniency and is not a necessary element of a generally benevolent statute.

The factors which have been abstracted here from some cases upholding indeterminate sentencing laws are by no means the only or even the best possible tests for the validity of administrative discretion over the sentences of prisoners. But they do reflect a judicial mood; the courts will not strike down as a denial of liberty statutes which are obviously designed to promote liberty. On the other hand, the Illinois cases $^{38}$ suggest that the courts will strike down grants of power to ad-

36 "It has uniformly been held that the indeterminate sentence is in legal effect a sentence for the maximum term. .. . There is clearly no merit in defendant's argument that the indeterminate sentence law violates the due process and equal protection clauses of the United States Constitution. A judgment pursuant to that law is both definite and certain ... ." People v. Kostal, 159 Cal. App. 2d 444, 452-53, 323 P.2d 1020, 1025-26 (1958).

37 See, e.g., In re Lee, 177 Cal. 690, 171 P. 958 (1918); People v. Kostal, 159 Cal. App. 2d 444, 452-53, 323 P.2d 1020, 1025-26 (1958). See also People v. Joyce, 246 Inl. 124, 134, 92 N.E. 607, 612 (1910): "If in said section 6 there is authority in the board of pardons to mitigate sentences in the manner provided therein, such action, if taken by the board, does not amount to a sentence of the prisoner."

38 See notes 29-32 supra and accompanying text. 
ministrative bodies to inflict punitive incarceration. Section 4205 is arguably in the latter category.

d. The escape theory. While most of the cases have employed theories similar to the ones previously discussed, several courts have used less plausible justifications. In an early case, the Supreme Court rejected an attack on a predecessor of section 4205 by holding that parole is in legal effect time spent at large after an escape and thus clearly not time spent serving a sentence. ${ }^{39}$ This analogy is unsound; while the "escape theory" might well be used to justify the refusal to credit time after the violation but before revocation, it is difficult to see how it could support the denial of credit for time spent lawfully in the custody of parole officials before violation. The weakness of the Court's reasoning is perhaps best demonstrated by the infrequency of the use of this rationale in later cases.

e. The consent theory. Another argument proferred in support of section 4205 amounts to a consent theory. Under the federal and most state systems in which credit is denied to parole violators, a prisoner who wishes to be placed on parole must agree that if he violates his parole he will return to prison and finish his sentence computed as of the date of original parole. It is argued that since the prisoner has agreed as a condition of his parole that a violation will result in forfeiture of credit for time spent on parole, he cannot complain when upon violation he is required to forfeit credit.40

If there is a constitutional right which prohibits the denial of credit on the basis of the finding of a parole violation by the board, the defeat of this right through a "waiver" demanded as a precondition to parole seems to be a somewhat more egregious form of the waiver under "coercion" struck down in Garrity v. New Jersey.11 In Garrity, the Court refused to validate a waiver of the fifth amendment freedom from selfincrimination which was "coerced" by the threat of the loss of public employment if the right were asserted. Similar reasoning would seem to indicate the invalidity of a waiver of due process rights "coerced" by making such a waiver a condition of parole. Even if such a waiver were otherwise permitted, however, the anticipatory nature of the waiver suggested by the "consent theory" would appear to render it completely invalid.

39 Anderson v. Corall, 263 U.S. 193, 196 (1923).

40 This was an alternative ground for the holding in Woods v. Steiner, 207 F. Supp. 945 (D. Md. 1962).

41385 U.S. 49 (1967). See also Uniformed Sanitation Men Ass'n v. Commissioner of Sanitation, 88 S. Ct. 1917 (1968); Gardner v. Broderick, 88 S. Ct. 1912 (1968). 
If, on the other hand, there is no constitutional right to be free of denial of credit by the parole board, the consent theory is unnecessary. Absent constitutional restrictions, the statute itself would be sufficient to justify denial of credit; discussions of "consent" become merely makeweight arguments addressed, at best, to the equities of the situation. In short, the consent theory seems unsuccessful if denial of credit involves constitutional rights and unnecessary if it does not.

\section{Failure of Equal Protection}

Even if denial of credit were only imposed pursuant to a proceeding including the full panoply of safeguards provided at a criminal trial, serious constitutional problems would remain. A threshold objection to section 4205 is that denial of credit for time spent on parole is an irrational sentencing device. Under section 4205, similar parolees committing similar crimes or noncriminal violations may receive vastly dissimilar treatment. For example, the parolee who serves three days on parole and is then convicted of a crime has only three days added to his custody by section 4205 ; a parolee who serves seven years on parole before being convicted of the identical crime has seven years of custody added by the denial of credit. ${ }^{42}$ Such disparate treatment of similar persons seems difficult to square with equal protection guarantees. ${ }^{43}$

\section{Incarceration for Noncriminal Acts}

Even if denial of credit were rationalized, that is, even if the amount of credit denied were determined on the basis of the nature of the parole violation committed, section 4205 would still present serious constitutional difficulties when applied to technical violations. Denial of credit, it has been argued, results in the imposition of sentence. Since

42 Whatever other constitutional problems it creates, the denial of credit for technical violations of parole or minor criminal offenses suggests the possibility of cruel and unusual punishment objections. See, e.g., Gibbs v. Blackwell, 354 F.2d 469 (5th Cir. 1965). In this action, the Fifth Circuit had a very sparse record before it and remanded the case to the district court for adjudication of the facts. But the circuit court indicated that on the basis of the facts before it, it appeared that appellant had lost seven years of parole time as a result of three instances of intoxication. The court's rather cautious opinion seemed to imply that if this were the case, the application of $\S 4205$ constituted cruel and unusual punishment. There is no record of the case on remand. It may only be assumed that the government, not wishing to risk a taint on $\S 4205$ 's character, released Gibbs. See also note 5 supra.

43 "When the existence of a distinct class is demonstrated, and it is further shown that the laws, as written or as applied, single out that class for different treatment not based on some reasonable classification, the guarantees of the Constitution have been violated." Hernandez v. Texas, 347 U.S. 475, 478 (1954). Within this framework, it seems unreasonable indeed to punish one class of parolees more harshly than another simply because the former has successfully served a longer period on parole. 
restrictions imposed on parolees as conditions of their parole are not offenses created by Congress but are instead established by the parole board itself, denial of credit for technical violations of parole results in the imposition of sentence for noncriminal acts. This would seem to constitute a denial of due process of law. ${ }^{44}$

\section{Probation: Denial of Credit for Parole Time in Context}

The problem of "denial of credit" is by no means limited to parole. Probation seems to present the closest analogy.45 When probation is revoked, the judge may impose any sentence which could have been passed for the original offense. ${ }^{46}$ The judge need not take into account the amount of time the prisoner had spent on probation prior to revocation when he passes sentence. Nor may the prisoner later claim that the time he spent on probation must be credited to the sentence imposed when probation was revoked. Inasmuch as the restrictions which accompany probation and parole are virtually identical, ${ }^{47}$ the problem of denial of credit in the two situations would appear indistinguishable.

There are, however, important differences. It must be remembered that the objection to denial of credit in the parole situation was predicated upon the contention that denial of credit results in the imposition of custody. But to attack probation on the ground that refusal to grant credit results in the imposition of custody at probation revocation would be meaningless; the whole idea of probation is that if during the probationary period the prisoner demonstrates himself to need incarceration, sentence will be imposed or executed.48 As a result the entire probation system, and not merely the denial of credit in

44 U.S. Const. amend. V \& XIV. These due process objections could be obviated if Congress passed laws establishing parole restrictions and made their violation criminal. The creation of a separate list of crimes for parolees might, however, constitute unreasonable discrimination against parolees in relation to the rest of society and present possible equal protection objections, at least with regard to some of the regulations. See note 43 supra. For example, it may plausibly be argued that, while it is reasonable to revoke the parole of a parolee who marries without permission of the parole board, it is unreasonable to make marriage a crime for parolees punishable by additional incarceration.

45 For a general discussion of probation revocation and the problems associated with it, see Note, Legal Aspects of Probation Revocation, 59 Colvm. L. REv. 311 (1959). The federal probation statute is 18 U.S.C. $\$ \$ 3651-56$ (1964).

46 See, e.g, Roberts v. United States, 131 F.2d 392 (5th Cir. 1942); Kaplan v. Hecht, 24 F.2d 664 (2d Cir. 1928).

47 Dressler, supra note 15, at 177-99 (1959).

48 Dominques v. Hunter, 170 F.2d 546, 547 (10th Cir. 1948); Kaplan v. Hecht, 24 F.2d 664, 665 (2d Cir. 1928). 
probation, is subject to the criticism that upon revocation there is imposition of new custody.

Despite numerous challenges, denying credit for time spent on probation has been upheld. In sustaining these laws, the courts have rejected the contention that a two stage sentencing process violates the double jeopardy prohibitions of the fifth amendment or any other constitutional prohibitions. ${ }^{49}$ Once the probation law itself is upheld, the provision that the time spent on probation shall not count toward the sentence finally imposed does not present any difficulties as long as the combined duration of the probation period and subsequent sentence are not in excess of the statutory maximum. As long as they do not exceed this maximum, the courts may presume that the judge took the probation period into account when passing final sentence. ${ }^{.0}$

When this total does exceed the statutory maximum for the offense committed, problems do arise. Nevertheless, courts have not hesitated to uphold the law in such situations. ${ }^{51}$ In doing so, they have applied to probation the theory which this comment has suggested should be rejected as applied to parole: they have considered probation to be a distinct form of custody which does not fulfill the statutory penalty for the crime. In the probation situation, this theory does seem to be more plausible than when applied to parole. While parole is an alternative means for the prisoner to complete the sentence he was serving in jail, probation is explicitly imposed by the judge and is wholly separate from any period of incarceration imposed. As one district court explained the distinction:

The probationer has a substantially different status from that of the parolee. The imposition of sentence in his case has been suspended and thus unlike the parolee he is not serving a sentence while on probation. ${ }^{52}$

There is no need to resort to a "contemplation" argument. It is far more plausible to view probation and incarceration as separate and

49 Kaplan v. Hecht, 24 F.2d 664, 665 (2d Cir. 1928).

50 This is the theory the federal courts have been developing to adjudicate the demands for credit for pretrial custody. On the one hand, a prisoner may not be required to serve longer than the statutory maximum for the crime of which he was convicted including time spent in prison awaiting trial or sentencing. On the other hand, in cases involving a sentence for less than the statutory maximum, it will be conclusively presumed that the trial court in imposing sentence gave the prisoner credit for the time spent in presentence custody. See Huber v. United States, 390 F.2d 544 (5th Cir. 1968); Dunn v. United States, 376 F.2d 191 (4th Cir. 1967); Stapf v. United States, 367 F.2d 326 (D.C. Cir. 1966).

51 See, e.g., Kaplan v. Hecht, 24 F.2d 664, 665 (2d Cir. 1928).

52 Hutchison v. Patterson, 267 F. Supp. 433, 434-35 (D. Colo. 1967) (emphasis in original). 
distinct parts of the sentence than it is to view parole and prison that way. ${ }^{53}$

\section{Policy Considerations}

The questions of policy turn on three major considerations: To what extent is it wise to empower administrative boards to make decisions which may substantially increase the sentence of prisoners? How effective is denial of credit as a deterrence device? Is denial of credit "fair" by our standards of justice?

It is clear that the answer to each of these questions is largely subjective. In answering the first question, it is necessary to balance the value of the increased powers of deterrence which denial of credit gives to the board against the rights of the individual in having sworn testimony, confrontation, subpoena power, and similar safeguards when faced with a hearing which may result in extensive incarceration. In answering the second question, it is necessary to balance the effectiveness of punitive measures in deterring misfeasance against the problems inherent in denial of credit as a rational sentencing device. In answering the "fairness" question, it is necessary to determine the equity of requiring the parolee to live in jeopardy not only of being returned to prison for a violation which may be trivial in nature, but of being returned for a period undiminished by the time spent in the custody of the parole board.

All of these questions may be reduced to the general one of determining the justification for having a device which permits the parole board to impose heavy sanctions on persons whom they find to be guilty of either a criminal or technical violation. In the case of a parolee suspected of a crime, a ready alternative to denial of credit is available: the parolee may be prosecuted. A device which permits the state to

53 There is in the federal courts a hybrid sentencing device between probation and parole which deserves some mention. When a man is convicted of a crime the judge may impose a sentence but suspend the execution of all but a maximum of six months imprisonment. This short term of imprisonment is to be followed by a period of probation not to exceed five years. 18 U.S.C. § 3651 (Supp. II, 1967). Such a "split sentence" may be imposed even when the statutory maximum sentence for the offense is less than five years. If the probation is violated, the court may order that the entire term of the original sentence be executed. See, e.g., Baber v. United States, 368 F.2d 463 (5th Cir. 1966). It is clear enough that as between probation and parole, this device could be characterized in one of two ways. It could be said that this is a partially deferred sentence-a certain amount of incarceration is executed, then there is a period of probation during which it is determined whether the rest is necessary. On the other hand, this type of probation looks very much like parole-it could be said that a sentence of this sort is the final sentence and the time spent on "probation" is in reality time spent on parole. The constitutionality of the device, under the analysis used in this comment, depends upon which characterization is accepted. 
impose sanctions on suspected criminals without the necessity of proving their guilt in a court of law is of questionable validity. In the case of a parolee who has committed a noncriminal violation such as leaving the jurisdiction or becoming intoxicated, the harshness of denial of credit may become unduly great if the period of parole has been at all lengthy. But as with the legal arguments, the policy considerations are not one-sided; their final resolution depends on one's priorities and values.

\section{Gonclusion}

Denial of credit to parole violators for the time they spent on parole is defended from constitutional attack on three main bases. First, while parole involves a certain amount of custody, it is much closer to freedom than it is to imprisonment and should not be credited to the prison sentence. Second, while the original sentence imposed on a federal prisoner does not include provision for an additional period on parole, federal judges in imposing sentence are aware that the parole laws may result in the prisoner's spending time on parole in addition to serving the entire sentence imposed under incarceration, and their contemplation of this results in the inclusion of parole custody in the original sentence. Third, even if denial of credit is administrative action affecting the duration of sentence, this is a perfectly valid practice; indeterminate sentencing laws are examples of administrative action affecting duration of sentence. On these bases, denial of credit is held valid.

The opponents of section 4205 view the matter differently. First, while parole is far less onerous than prison, it is nonetheless a form of deprivation of liberty which most assuredly could not be imposed without due process of law. Second, they assert that the contemplation argument is not only a bit contrived, but could be used to justify any legislative grant of power over prisoners' sentences. Third, it is asserted that unlike indeterminate sentencing laws, section 4205 is indeed contrived to deprive persons of liberty and thus falls under the fifth amendment prohibition.

It must be admitted that the constitutional attack on section 4205 does not demolish the arguments in its favor. Yet a court convinced of the unfairness of section 4205 has ample grounds to declare it invalid. And most assuredly, Congress would be well advised to consider emulating the recent New York example ${ }^{54}$ and abolishing the denial of credit provisions in its parole statute. 